\title{
The use of homeopathy to prevent symptoms of human flu and acute respiratory infections: a double- blind, randomized, placebo-controlled clinical trial with 600 children from Brazilian Public Health Service
}

\author{
Carlos Lyrio ${ }^{1}$, Camila Monteiro Siqueira², Venicio F. Veiga ${ }^{2}$, Fortune \\ Homsani $^{2}$, Ana Luiza Marques ${ }^{2}$, Jorge Biolchini³ ${ }^{3}$ Flavio Dantas ${ }^{4}$, Haroldo \\ José de Matos ${ }^{5}$, Sonia Regina Lambert Passos ${ }^{6}$, José Nelson Couceiro ${ }^{1}$, Carla \\ Holandino $^{1}$
}

\author{
${ }^{1}$ Roberto Costa Institute, Petrópolis, Brazil \\ ${ }^{2}$ Federal University of Rio de Janeiro, Rio de Janeiro, Brazil \\ ${ }^{3}$ Pontifice Catholic University, Rio de Janeiro, Brazil \\ ${ }^{4}$ Federal University of São Paulo, São Paulo, Brazil \\ ${ }^{5}$ Rio de Janeiro State University, Rio de Janeiro, Brazil \\ ${ }^{6}$ Oswaldo Cruz Foundation, Rio de Janeiro, Brazil
}

\begin{abstract}
In Brazil, homeopathy was implemented in the Public Health Service through the National Policy on Complementary and Integrative Practices of the Health Ministry, published in 2006. Homeopathy appears as a very interesting therapy to be used in the Public Health Services since its medicines are compounded at a very low cost. Considering this interesting scenario to develop research in the Public Health, the Family Health Program (FHP) in Petropolis and the Faculty of Pharmacy at UFRJ started a partnership with the Roberto Costa Institute. A homeopathy clinical trial, employing a control protocol (double-blind, randomized, placebo-controlled), was developed as a result of this partnership starting in April 2009 and ending in April 2010. This clinical trial, approved by the Ethics Committee at UFRJ, number 194/08, aimed to evaluate the efficacy of two types of biotherapics to prevent symptoms of both flu and acute respiratory infections, compared to placebo (ethanol 30\%). The biotherapics tested were ARI (Acute Respiratory Infection) and InfluBio. ARI is a homeopathic complex containing three different microorganisms related to respiratory infection while InfluBio is a biotherapic compounded from infectious influenza A virus. Before the development of this clinical trial, ARI had been used routinely in FHP, in Petropolis, to prevent acute respiratory infections in patients. The qualitative results obtained from this application suggested that this medicine has a prophylactic potential in the treatment of respiratory diseases. Additionally, we evaluated the antiviral activity of InfluBio using in vitro methodology and the promising results obtained motivated our group to test it in a clinical trial. With this aim, 600 children, from 1 to 5 years of age, were selected by physicians in 21 units of FHP, following the inclusion/exclusion criteria. For 1 month (April 2009), the children received daily, in a blind manner, the test solutions (placebo, ARI, InfluBio) in the posology of 1 drop
\end{abstract}


per year of age. After 30 days, the use of these solutions was interrupted, and the health agents monitored the children for the subsequent twelve months, registering, in a specific questionnaire, symptoms of flu and acute respiratory infections. The respiratory symptoms that were to be reported were: runny nose, fever, prostration, myalgia, cough and headache. In the occurrence of one or more of these symptoms, the health agents evaluated the necessity of intervention by the physician. Of the 600 children, 450 completed the planned monitoring. The main reasons why 150 quit the treatment were change of address and parents' abandonment. Additionally, no death was recorded and all the children presented good clinical evolution. In the case of the children who received placebo, the frequency of episodes diagnosed as acute respiratory infection/flu was three times higher when compared to those that received the ARI and InfluBio samples, considering the superior limit of the interquartile interval. Moreover, children treated with these biotherapics did not present any or presented only a single episode of ARI/Flu. These results showed that both biotherapics tested were statistically higher $(p<0.01)$ than placebo, i.e., the biotherapics minimized the frequency of symptomatic episodes of flu. Besides the proved efficacy of homeopathic medicines, the homeopathic treatment presents the additional advantages that include the low cost of medicine compounding and the absence of registered adverse effects, which put this therapeutic as a very useful option for the Public Health Services.

Keywords: Clinical trial, Flu, Biotherapic

\title{
O uso da homeopatia para prevenir sintomas da gripe humana e infecção respiratória aguda: um estudo clínico duplo cego, randomizado, placebo controlado com 600 crianças do Serviço Público de Sáude do Brasil
}

\begin{abstract}
RESUMO
No Brasil, a homeopatia foi implementada no Serviço Público de Saúde, através da Política Nacional de Práticas Integrativas e Complementares do Ministério da Saúde, publicada em 2006. A homeopatia surge como uma terapia muito interessante para ser usada no serviço público de saúde uma vez que seus medicamentos tem um custo muito baixo. Considerando este cenário interessante para desenvolver uma pesquisa em Saúde Pública, o Programa de Saúde da Família (PSF) de Petrópolis e a Faculdade de Farmácia da UFRJ iniciaram uma parceria com o Instituto Roberto Costa. Um estudo clínico com homeopatia, empregando um protocolo padrão (duplo-cego, randomizado, placebo controlado), foi desenvolvido como um resultado desta parceria, iniciando em abril de 2009 e terminando em abril de 2010. Este estudo clínico, aprovado pelo Comitê de Ética da UFRJ, número 194/08, teve como objetivo avaliar a eficácia de dois tipos de bioterápicos para prevenir sintomas da gripe e de infecções respiratórias agudas, em comparação com placebo (etanol 30\%). O bioterápicos testados foram IRA (Infecção Respiratória Aguda) e InfluBio. IRA é um complexo homeopático contendo três diferentes microrganismos relacionados com a infecção respiratória, enquanto que InfluBio é um bioterápico preparado a partir do vírus influenza infeccioso. Antes do desenvolvimento deste ensaio clínico, o IRA era usado rotineiramente em Petrópolis para a profilaxia de infecções respiratórias
\end{abstract}


agudas em pacientes dos PSF. Os resultados qualitativos obtidos com este pacientes evidenciaram que o bioterápico IRA possui um potencial profilático contra doenças respiratórias. Além disso, empregando uma metodologia in vitro, nosso grupo de pesquisa investigou a atividade antiviral de InfluBio. Os promissores resultados obtidos nos motivaram a desenvolver um ensaio clínico visando avaliar o potencial antiviral deste bioterápico. Com este objetivo, 600 crianças, de 1 a 5 anos de idade, foram selecionadas por médicos em 21 unidades dos PSF de Petrópolis, seguindo os critérios de inclusão / exclusão. Por 1 mês (Abril 2009), as crianças receberam diariamente, de maneira cega, as soluções teste (placebo, IRA, InfluBio) numa posologia de 1 gota/idade. Após 30 dias, o uso dessas soluções foi interrompido e os agentes de saúde monitoraram as crianças pelos 12 meses subsequentes, registrando, em um questionário específico, os sintomas atribuídos à gripe e às infecções respiratórias agudas. Os sintomas respiratórios considerados foram: coriza, febre, prostração, mialgia, tosse e dor de cabeça. Na ocorrência de um ou mais destes sintomas, os agentes de saúde avaliavam a necessidade de intervenção médica. Das 600 crianças, 450 concluíram todo o protocolo experimental, como o planejado. As principais razões que levaram à desistência das 150 crianças foram, dentre outras, mudança de endereço e abandono da pesquisa pelos pais. Além disso, nenhuma morte foi registrada e todas as crianças apresentaram boa evolução clínica. No caso das crianças que receberam placebo, a freqüência de episódios diagnosticada como infecção respiratória aguda / gripe foi três vezes maior quando comparada às crianças que receberam IRA e InfluBio, considerando o limite superior do intervalo interquartil. Além disso, as crianças tratadas com estes bioterápicos não apresentaram ou apresentaram um único episódio de IRA / gripe. Estes resultados mostraram que ambos os bioterápicos testados foram estatisticamente superiores $(p<0,01)$ quando comparados ao grupo placebo, ou seja, o emprego dos bioterápicos minimizou a freqüência de episódios sintomáticos de gripe. Além da eficácia comprovada destes medicamentos, o tratamento homeopático apresenta outras vantagens adicionais que incluem o baixo custo e a ausência de efeitos adversos, o que faz com que esta seja uma opção terapêutica muito útil para os Serviços Públicos de Saúde.

Palavras-chave: Estudo clínico, Gripe, Bioterápicos.

\section{(c)) BY-NC-ND Licensed to GIRI}

Support: CAPES and Roberto Costa Institute

Conflict of interest: authors declare there is no conflict of interest

Correspondence author: Carlos Lyrio, carloslyrio@robertocosta.org.br .

How to cite this article: Surname Lyrio C, Siqueira CM, Veiga VF, Homsani F, Marques AL, Biolchini J, Dantas F, Matos HJ, Passos SML, Couceiro JN, Holandino C. The use of homeopathy to prevent symptoms of human flu and acute respiratory infections: a double-blind, randomized, placebo-controlled clinical trial with 600 children from Brazilian Public Health Service. Int J High Dilution Res [online]. 2011 [cited YYYY Month dd]; 10(36): 174-176. Proceedings of the XXV GIRI Symposium and VIII CBFH; 2011 Sep 04-07; Foz do Iguaçu (Brazil). GIRI and ABFH; 2011; Available from: http://www.feg.unesp.br/ ojs/index.php/ijhdr/article/view/499/513 